\title{
Density and coverage of seagrass at Tunggul Beach, Paciran, Lamongan, East Java
}

\author{
Linggar Budi Nuansa ${ }^{1 *}$, Asri Sawiji ${ }^{1}$, Toha Muslih ${ }^{2}$ \\ ${ }^{1}$ Marine Science Department, Faculty of Science and Technology, UIN Sunan Ampel Surabaya, Indonesia \\ ${ }^{2}$ Marine and Fishery Office of Lamongan Regency, Indonesia \\ *E-mail: linggartuan99@gmail.com
}

\begin{abstract}
Seagrass is an ecosystem that has an important role as nursery and spawning ground in the life cycle in the sea. Increased human activity and climate change are feared to damage seagrass ecosystems so it is important to maintain their sustainability. This study aims to find out the composition of species, density and coverage of seagrass at Tunggul Beach, Paciran, Lamongan. This research was conducted on August until October 2020 by applying purposive sampling method as the basis for determining location point at 2 stations, with 3 substations at each station with transect line along $100 \mathrm{~m}$. Seagrass data retrieval method using transect quadrant $50 \times 50 \mathrm{~cm}$ to observe the coverage and calculate seagrass stand. The results showed the type of seagrass found on Tunggul Beach are two species, Thalassia hemprichii and Enhalus acroides. Seagrass density value at station 1 is rather tight with a density value of $92.48 \%$ and at station 2 is rare with a value of $73.09 \%$. The percentage of seagrass coverage at station 1 indicates a solid category with a coverage value of $54.92 \%$ and in the station 2 shows a medium coverage category with a value of $31.25 \%$.
\end{abstract}

Keywords: seagrass coverage, seagrass density, Thalassia hemprichii, Enhalus acroides.

\section{INTRODUCTION}

Lamongan regency is one of the regencies located in East Java considered to have a high level of biodiversity, especially in the water area. One of which is Tunggul beach area located in Tunggul Village, Paciran District. This area has high resource potential of seagrass ecosystems. Seagrass ecosystem is one of the ecosystems in the waters dominated by seagrass vegetation. Ecologically, seagrass ecosystems have an important role for coastal areas, among others, as the main primary productivity in the waters, stabilizing the basic substrate of the waters with its rooting system that serves as sediment trapping, spawning ground, nursery ground, and feeding ground for marine biota, $\mathrm{O}_{2}$ producers and reducing $\mathrm{CO}_{2}$ in the water [1].

However, seagrass beds are fragile ecosystems. The decrease in area and density of seagrass ecosystem is in line with the high development in coastal areas resulting in environmental degradation. The purpose of this research is to examine the density and coverage of seagrasses and their ecosystem conditions in the framework of one of the efforts to manage and preserve coastal areas in the waters of Tunggul Beach. This research was conducted because there was no preliminary study on the condition of the seagrass ecosystem in the related location. Information on seagrass conditions including seagrass density and coverage is expected to be initial information as further research to be carried out in related locations as well as information in efforts to manage coastal ecosystems.

\section{METHODS \\ Sample Collection}

This research was conducted in Tunggul Beach, Lamongan, East Java, on August-October 2020. The research location focused on two sampling station location points with each station consisting of three (3) sub stations (Figure-1). Seagrass data collection is done using line transect method in each substation with a length of $100 \mathrm{~m}$ each and the distance of one substation with another substation is $50 \mathrm{~m}$ so that the total observation area is $100 \times 100 \mathrm{~m}^{2}$. Seagrass observation is done by calculating the number of seagrass stand and percentage of seagrass coverage in transect quadrant measuring $50 \times 50 \mathrm{~cm}^{2}$ (Figure-2).

In-situ measurement of aquatic parameter data includes physical parameters: water depth, brightness, current velocity, and substrate. The methods and tools used in measuring the physical parameters of the waters were presented at Table-1.

Table-1. Method and tools used in measuring physical water parameters

\begin{tabular}{|l|c|c|}
\hline \multicolumn{1}{|c|}{ Parameters } & Unit & Methods and Tool \\
\hline Water depth & $\mathrm{m}$ & Roll Meter/ visual \\
\hline Brightness & $\mathrm{m}$ & Secchi disc/visual \\
\hline $\begin{array}{l}\text { Current } \\
\text { velocity }\end{array}$ & $\mathrm{cm} / \mathrm{s}$ & $\begin{array}{c}\text { Bottle and } \\
\text { rope/Langrangian method }\end{array}$ \\
\hline Substrate & - & Visual \\
\hline
\end{tabular}




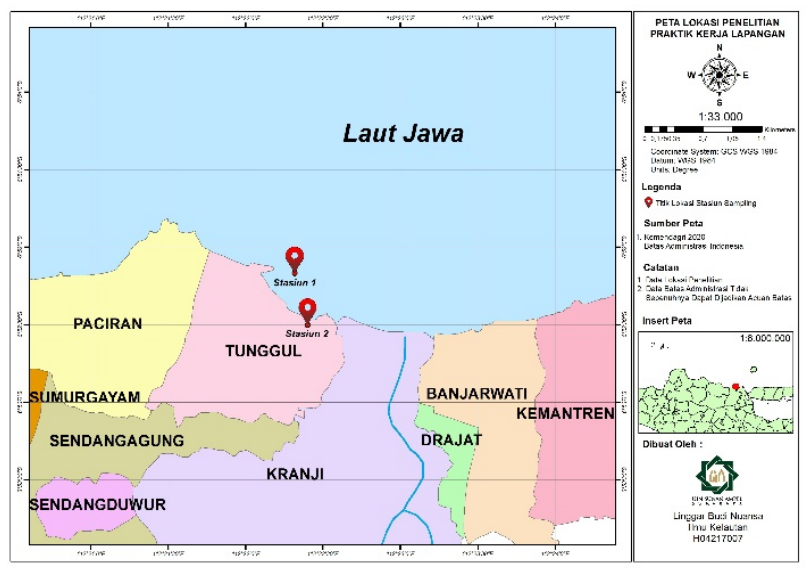

Figure-1. Research site

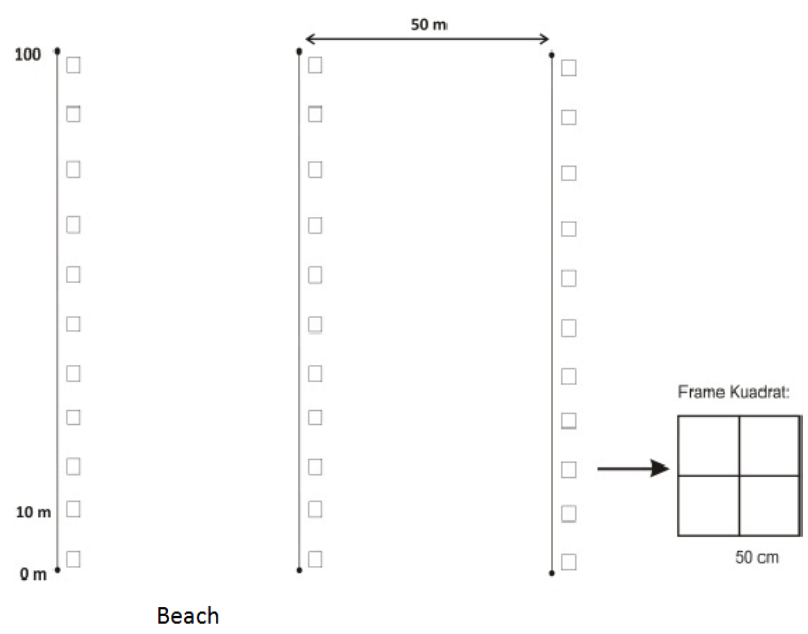

Figure-2. Sampling design

\section{Data Analysis}

Data obtained from observations were then analysed to determine the seagrass density, seagrass coverage (\%), and physical water parameters. Seagrass density is the total number of individual in one unit area expressed in units of area. The category of seagrass density is shown in Table-2. Seagrass density calculated using the calculation formula of Snedecor and Cochran [2]:

$K i=\frac{\sum D i}{\sum n i X A}$

where $K i$ is species density, $\sum D i$ is total number of stands of each species, $\sum n i$ is total number of quadrants, and $A$ is transect area quadrant $\left(\mathrm{m}^{2}\right)$.

Seagrass coverage reveals the area covered by seagrass. The category of seagrass coverage is shown in Table-2.The calculation of seagrass coverage in one quadrant is done by summing the value of the coverage in each small box in the quadrant and dividing it by the number of small squares, which is four. Percentage of seagrass coverage in a transect quadrant is calculated using this formula [3]:

seagras coverage $(\%)=\frac{\text { seagrass coverage values (one quadrant) }}{4}$

From the calculation of the percentage of seagrass for each quadrant then the average percentage of seagrass coverage is calculated for one station using this formula [3]:

seagras coverage $(\%)=\frac{\text { seagrass coverage of the entire quadrant }}{\text { number of quadrants }}$

Table-2. Seagrass density based scale category

\begin{tabular}{|c|c|c|}
\hline Scale & Density (ind $\left./ \mathbf{m}^{\mathbf{2}}\right)$ & Category \\
\hline 5 & $5>175$ & Very tights \\
\hline 4 & $4125-175$ & Tights \\
\hline 3 & $75-125$ & Rather tights \\
\hline 2 & $25-75$ & Seldom \\
\hline 1 & $<25$ & Very rare \\
\hline
\end{tabular}

Table-3. Seagrass coverage category

\begin{tabular}{|c|c|}
\hline Coverage (\%) & Category \\
\hline $0-25$ & Rare \\
\hline $26-50$ & Moderate \\
\hline $51-75$ & Dense \\
\hline $76-100$ & Very Dense \\
\hline
\end{tabular}

\section{RESULTS AND DISCUSSIONS}

Seagrass vegetation in Tunggul Beach is a mixed type of vegetation consisting of two seagrass species, Enhalus acroides and Thalassia hemprichii. The seagrass species with the highest number of stands was dominated by Enhalus acroides with 338 ind (station 1) and 419 ind (station 2) stands and an average stand of 126 ind. This seagrass is most often found and dominates the seagrass beds because it has a high survival capacity [4]. This species is most easily recognized in the water due to its large size compared to other seagrass species.

The dominance of Enhalus acroides (Figure-3) in the waters of Tunggul Beach is inseparable from the characteristics of its habitat that lives in sandy or charcoal sand substrates [5], according to the substrate of Tunggul Beach which tends to be charcoal sand, although there are some points with sandy clay or fine sand substrates. Enhalus acroides have thick, wide leaves, and a length of up to 1 meter so that it has room for larger photosynthesis. [6] states the morphology of seagrass species in the form of upright plants with long leaves and large enough, supporting its ability to have high resistance to various environmental conditions. Seagrass Enhalus acroides have larger roots compared to other species and are able to survive in waters that tend to be murky or muddy.

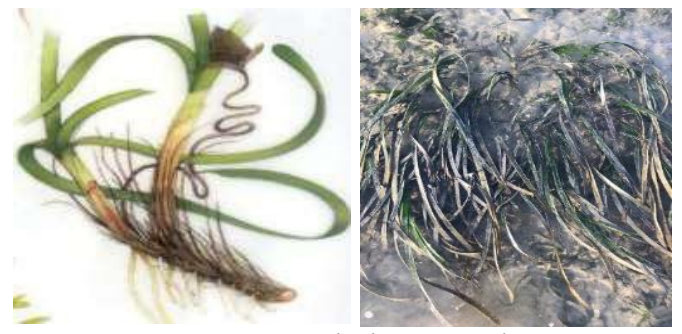

Figure-3. Enhalus acroides

Species Thalassia hemprichii (Figure-4) had the second highest average number of stands (102 inds) with 425 ind stands (station 1) and 184 (station 2). Thalassia hemprichii is found in waters with muddy substrates and charcoal sand according to the sandy base substrate of Tunggul Beach waters with a mixture of dead corals and fine sandy. This species generally co-lives with the species 
Enhalus acroides [5]. This type of seagrass has a smaller morphology of leaves so that it can be more numerous compared to seagrass species that have large leaves [7]. Thalassia hemprichii leaf strands are ribbon-shaped with rounded ends and there are brown lines or patches on the surface. On each stand there are 2-5 leaves with a leaf length of 6-30 $\mathrm{cm}$ and a width of 5-10 $\mathrm{mm}$ [8].

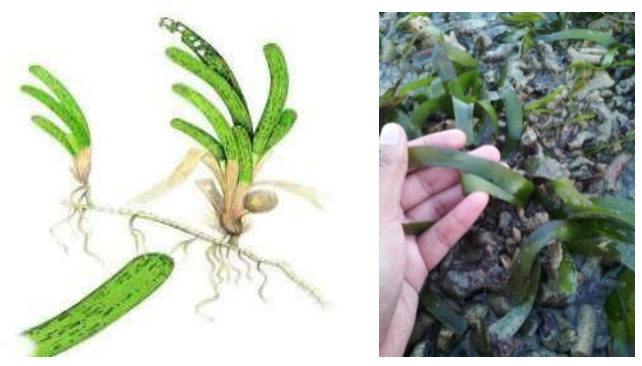

Figure-4. Thalassia hemprichii

The results showed a different number of stands at each location. Differences in the number of stands are influenced by various factors including seagrass species, water base substrate conditions, high currents and waves, organic material content, and other environmental factors such as the activity of organisms associated in them [9]. Both types of seagrass generally live in areas with sandy to rocky substrates. Enhalus acroides and Thalassia hemprichii are seagrass species that have a larger morphology than others so that they have greater competitiveness than other types [7].

The density value of the seagrass ecosystem at Tunggul Beach has different values at each station. The density of seagrass in station 1 at 92.48 ind $\mathrm{m}^{2}$. Whereas at Station 2 at $73.09 \mathrm{ind} / \mathrm{m}^{2}$. The high density of seagrass is related to habitat characteristics such as substrate type and a fairly shallow depth because the presence of seagrass is influenced by the penetration of light needed by seagrass for photosynthesis [10]. The difference in density value can be caused by several factors, among others, the characteristics of different substrates between stations, so that seagrass distribution is uneven, in addition to environmental factors such as human activities around the research site causing water physics conditions to be slightly disturbed thus affecting seagrass ecosystems.

This indicates that the better the water physics condition, the higher the seagrass density value in these waters. The difference in seagrass density value is also caused by the composition of seagrass species, morphology, and its community [11]. According to [12] seagrass density is influenced by environmental factors in which seagrass grows such as depth, brightness, current, and substrate type. Analysis of seagrass density refers to the category of seagrass density based on [13], so the seagrass ecosystem at station 1 is in the rather tights category with seagrass density values ranging from 75-125 ind $/ \mathrm{m}^{2}$, while the seagrass density at station 2 is in the rarely category with a density value ranging between 25 $75 \mathrm{ind} / \mathrm{m}^{2}$. Results seagrass density per species in the study site shown in Figure-5, where the density value Enhalus acroides at station 1 at $40.97 \mathrm{ind} / \mathrm{m}^{2}$ and Thalassia hemprichii of $51.52 \mathrm{ind} / \mathrm{m}^{2}$. While at the station 2 density value acroides Enhalus of $50.97 \mathrm{ind} / \mathrm{m}^{2}$ and Thalassia acroides of $22.30 \mathrm{ind} / \mathrm{m}^{2}$.

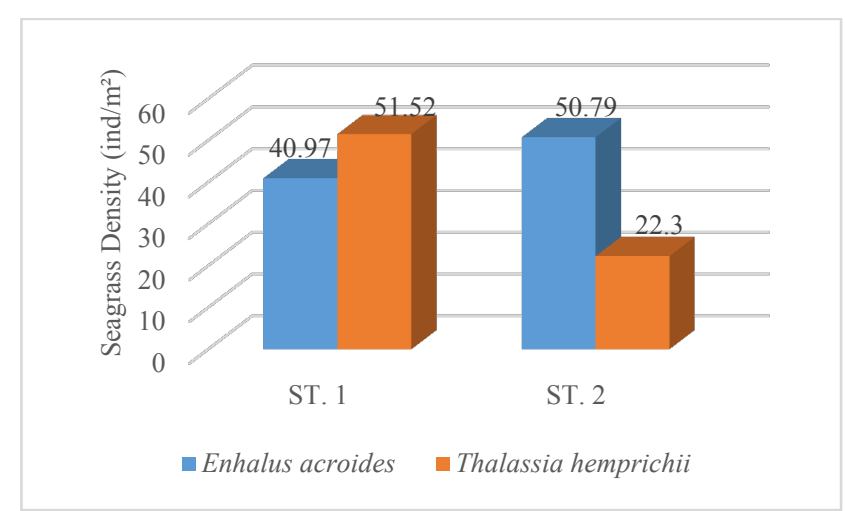

Figure-5. Seagrass density at Tunggul Beach

The highest density of seagrass species on Tunggul Beach at the first station is Thalassia hemprichii with a density of $51.52 \mathrm{ind} / \mathrm{m}^{2}$. While at the second station the highest density in species Enhalus acroides with a density value of $50,79 \mathrm{ind} / \mathrm{m} 2$. Station 1 has a higher density compared to station 2 . This can be caused by different substrate conditions, current velocity, and also other environmental activities. The texture of sediment with sandy clay allows the sediment at the bottom to easily rise to the water column due to the current so that the water becomes murky. At station 1 which is near breakwater or increasingly heading out to sea has a substrate of charcoal sand sediment so that the water conditions are not so murky despite the high currents. This condition will not prevent sunlight from entering the water, so the process of photosynthesis will not be disturbed and seagrass growth rate will also not be impaired. According to [14], light has a positive impact on seagrass growth, because seagrass needs it for photosynthesis and metabolism in its body. Seagrass density is also influenced by the depth and brightness of the waters, as well as the basic substrate of the waters [12].

While at station 2 seagrass density belongs to the category is rarely caused by one of the types of substrates that are generally sandy on some plots, so it is easy to climb into the water column when exposed to currents. The presence of solids floating in the water column and attached to the seagrass leaves causes incoming sunlight to be blocked, thus disrupting the process of seagrass photosynthesis resulting in seagrass growth rate. In addition, station 2 is located at the southern end close to the coast and the pier where human activities such as tourist activities, fishing by local fishermen, and the search for shellfish are the causes of disruption of ecosystems in the waters.

Percentage of seagrass illustrates how wide a seagrass bed covers a water. Seagrass coverage can only be seen from the morphology of the seagrass which has succeeded in covering the waters, so that the value of the coverage is not always proportional to the density value seen from the number of stands. The results of the percentage of seagrass coverage in Tunggul Beach waters are shown in Table-4.

Table-4. Coverage of seagrass

\begin{tabular}{|c|c|c|}
\hline Location & Coverage of seagrass (\%) & Category \\
\hline Station 1 & 54.92 & Dense \\
\hline Station 2 & 31.25 & Moderate \\
\hline Average & 43.09 & \\
\hline
\end{tabular}


Results of analysis of the percentage value of seagrass coverage in Tunggul Beach waters have an average of $43.09 \%$ with a coverage value at station 1 of $54.92 \%$ and station 2 of $31.25 \%$. Based on the percentage value at station 1 , the seagrass coverage category is included in the dense category while at station 2 it is included in the moderate category. The percentage value of seagrass coverage is influenced by the width of the leaf strands. The wider the feeding strands the ability to cover the substrate or the bottom of the water is also greater [15]. Seagrasses with great morphology such as those found in Tunggul Beach namely Enhalus acroides and Thalassia hemprichii are able to dominate the closure of seagrass species in the water. The high closure of both types of seagrass is related to its adaptability to all types of substrates from smooth to coarse or coarse sand. Large seagrass individuals will have a higher closing value than small ones that will have a smaller percentage of coverage [9].

Poor aquatic conditions can affect the life of organisms either directly or indirectly, otherwise good aquatic conditions will support the life of organisms in them including seagrass ecosystems. Water parameters related to seagrass growth include depth, brightness, current speed, and substrate. The measurement of water parameters is presented in Table-5.

Table-5. Mean value of physical water parameters

\begin{tabular}{|l|c|c|c|}
\hline \multicolumn{1}{|c|}{ Parameter } & Unit & Station 1 & Station 2 \\
\hline Water depth & meters & 0.51 & 0.56 \\
\hline Brightness & meters & 0.51 & 0.35 \\
\hline Current velocity & $\mathrm{cm} / \mathrm{s}$ & 6.85 & 5.14 \\
\hline Substrate & - & Coral sand & Sand \\
\hline
\end{tabular}

Depth of the waters affects the condition of an organism. Depth changes affect water pressure, temperature, brightness and nutrients. The depth at the study site shows a range of 0.51-0.56 meters. The distribution of seagrass is in the water conditions that are not too deep [16]. The depth of the water is related to the penetration of sunlight that can penetrate the water column. The brightness at station 1 reaches $100 \%$ with a value of $0.51 \mathrm{~m}$, while at station 2 it only reaches $0.35 \mathrm{~m}$ which means that the turbidity of the water in this location is quite high. One of the factors that prevent sunlight from entering the waters is sediment mixing. Sunlight is needed by seagrass in the photosynthesis process and plays a role in the productivity and availability of nutrients in the water [17].

The current velocity at the research location is included in the very slow current category with a value of $6.85 \mathrm{~cm} / \mathrm{s}$ at station 1 and $5.14 \mathrm{~cm} / \mathrm{s}$. The currents that are high enough can cause the waters to easily experience turbidity, but the relatively calm currents also cause the leaf surface to be more easily overgrown by epiphytic algae and covered by sediment trapped at the bottom of the waters, especially in areas with muddy substrates. The substrate conditions at the study site were dominated by sand. At station 1 the substrate is dominated by sand mixed with coral fragments, while at station 2 it is dominated by fine sand. Fine sand substrate has a higher nutrient content than coarse substrate such as coral [18]. The substrate plays a role in stabilizing seagrass life, a medium for growth, protects the seagrass from currents and waves, and provides nutrients for the seagrass.

\section{CONCLUSIONS}

The composition of seagrass species found in Tunggul Beach waters consists of two species, Enhalus acoroides and Thalassia hemprichii. The density of seagrass ecosystem at station 1 is in the rather tights category while the seagrass density at station 2 is in the rarely category. The percentage of seagrass coverage at station 1 shows a dense category and at the station 2 shows a moderate coverage category. The physical water parameters conditions at Tunggul Beach support seagrass life and growth.

\section{ACKNOWLEDGMENT}

The authors thank to Marine and Fishery Office of Lamongan Regency for funding this research.

\section{REFERENCES}

[1] Nybakken, J. W. 1998. Suatu Pendekatan Ekologi. Gramedia. Jakarta.

[2] Agustina, A. 2016. Kerapatan dan Biomassa Lamun Thalassia hemprichii di Pantai Nirwana Kota Padang Provinsi Sumatera Barat. Skripsi. Universitas Riau. Pekanbaru.

[3] Rahmawati, S., A. Irawan, I.H. Supriyadi, M.H. Azkab. 2014. Panduan Monitoring Padang Lamun. Editor: Hutomo, M. dan A. Nontji. COREMAP CTI, Pusat Penelitian Oseanografi, Lembaga Ilmu Pengetahuan Indonesia (LIPI). Jakarta.

[4] Lanuru, M. 2011. Sediment characteristics affecting the success of seagrass (Enhalus acoroides) transplantation in the West Coast of South Sulawesi, Indonesia. $3 r d$ International Conference on Chemical, Biological and Environmental Engineering. Vol. 20. IACSIT Press, Singapore: 97102.

[5] Sosetiono. 2004. Fauna Padang Lamun. Lembaga Ilmu Pengetahuan Indonesia (LIPI). Jakarta.

[6] Waycott, M., K. McMahon, J. Mellors, A. Calladine, and D. Kleine. 2004. A Guide to Tropical Seagrass of the Indo-West Pacific. James Cook University. Townsville.

7] Fauziyah, I. M. 2004. Struktur Komunitas Padang Lamun di Pantai Jibar Sanur Bali. Skripsi. Jurusan Ilmu dan Teknologi Kelautan, Fakultas Perikanan dan Ilmu Kelautan, IPB. Bogor.

[8] Latuconsina, H. 2012. Komposisi Spesies dan Struktur Komunitas Ikan Padang Lamun di Perairan Tanjung Tiram Teluk Ambon Dalam. Jurnal Ilmu dan Teknologi Kelautan Tropis. 4(1): 35-46.

[9] Short, F. T. and R. G. Coles. 2003. Global Seagrass Research Method. Elsevier Science. Amsterdam.

[10] Eki, N. Y., F. Sahami, dan S. N. Hamzah. 2013. Kerapatan dan Keanekaragaman Jenis Lamun di Desa Ponelo, Kecamatan Ponelo Kepulauan, Kabupaten Gorontalo Utara. Jurnal Ilmiah Perikanan dan Kelautan. 1(2): 65-70. https://doi.org/10.37905/.v1i2.1222

[11] Isabella, D. C. V. 2011. Analisis Keberadaan Perifiton dan Kaitannya dengan Parameter FisikaKimia dan Karakteristik Padang Lamun di Pulau 
Pari. Tesis. Sekolah Pascasarjana Institut Pertanian Bogor. Bogor.

[12] Kiswara, W. 1997. Struktur Komunitas Padang Lamun Perairan Indonesia. Lembaga Ilmu Pengetahuan Indonesia (LIPI). Jakarta.

[13] Braun-Blanquet, J. 1965. Plant Sociology: The Study of Plant Communities. Hafner.London.

[14] Gruber, R. K. and W. M. Kemp. 2010. Feedback Effects in a Coastal-Canopy Forming Submersed Plant Bed. Limnology and Oceanography. 55(6): 2285-2298.

[15] Fahruddin, M., Y. Fredinan, dan S. Indradjad. 2017. Kerapatan dan Penutupan Ekosistem Lamun di Pesisir Desa Bahoi, Sulawesi Utara. Jurnal Ilmu dan Teknologi Kelautan Tropis. 9(1): 375-383.

[16] Dahuri, R. 2003. Keanekaragaman Hayati Laut: Aset Pembangunan Berkelanjutan Indonesia. PT Gramedia Pustaka Utama. Jakarta.

[17] Peterson, B. J. and K. L. J. Heck. 1999. The Potential for Suspension Feeding Bivalves to Increase Seagrass Productivity. Journal Exp. Mar. Biol. Ecology. 240(1): 37-52.

[18] Tomascik, T., A. J. Moh., A. Nontji, and M. F. Moora. 1999. The Ecology of the Indonesian Seas. Dalhouise Univ. Kanada. 